\title{
Dam Policy: The Need For Global Governance
}

Peter Longo, University of Nebraska-Kearney, USA Richard Cummings, University of Wisconsin-Whitewater, USA

\begin{abstract}
Dams have long fascinated engineers, policymakers, and citizens-at-large. No doubt the engineering and architectural details of physical construction of dams are worth study and scrutiny, but it is the human dimension that complicates dam policies. Dams can result in tremendous negative impacts on human populations. Yet, dams provide a source of renewable energy, hydroelectric power. Analyzing these issues in a global perspective offers strategies for policy makers to consider. This paper will analyze the negative impact dams have on humans, illustrate the hydroelectric push for dams and how they impact food production. Finally, global policy strategies will be offered with consideration of environmental accounting and an indication of the future of water and food.
\end{abstract}

Keywords: International Dam Policy; Energy Policy; Renewable Energy; Environmental Accounting

\section{INTRODUCTION}

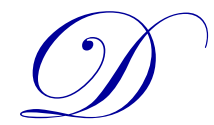

ams are promoted and critiqued from multiple perspectives. The multiple and varied demands often provide conflicting public policies or results without formal inputs. While policies are often less than satisfying, well-constructed dam policies should be of interest on a global scale. The scale should be in the public interest, regardless of state identity and corporate profits.

Environmental policies dealing with the management of limited natural resources demand the careful attention from citizens and lawmakers. Dams have tremendous negative impacts on human populations ranging from death to food production. Proponents of dams suggest that dam generation of hydroelectric power is an essential renewable energy source. Policies driven by the competing forces should be placed in a global public interest context.

This paper will analyze the negative impact dams have on humans, illustrate the hydroelectric push for dams and how they impact food production. Finally, global policy strategies will be offered with consideration of environmental accounting and an indication of the future of water and food.

\section{HUMAN IMPACT: LESSONS FOR POLICYMAKERS}

The negative concerns regarding dams have been numerous and prolonged. The 2000 report by the World Commission on Dams provided a landmark for dam criticism. The World Commission on Dams in 2000 Executive Summary found:

"Dams have made an important and significant contribution to human development... in too many cases an unacceptable and often unnecessary price has been paid to secure those benefits, especially in social and environmental terms, by people displaced, by communities downstream, by taxpayers and by the natural environment."

The 2000 report, supported by the World Bank, underscored the importance of social, political, and human impacts dams have on populations. Despite this compelling report, dam projects proceeded without formal checks 
by global governance mechanisms. Rather, typical market forces and cost benefit analysis seem too often to dictate the dam policy process. The World Commission ought to, at the very least, raise the human dimension in the global political arena. Yet, over a decade later the World Bank retreated from the aforementioned position. Dam policy lacks governmental principles and rather is guided by corporate powers. The demand for renewable energy sources has made hydroelectric power an important option for policymakers and thus the human impact slides down the policy scale.

A comprehensive report by Richter and Postel, et al. provided more compelling arguments against dams and dam developments. Specifically, Richter and Postel, et al. found: "Our conservative estimate of 472 million suggests that the number of people potentially affected downstream of large dams exceeds by six to 12 times the number directly displaced by these structures (previously estimated at 40-80 million; WCD, 2000)" (2010:15).

These negative impacts harm the least powerful people. There is a tremendous omission of governing access points for the various citizens. The policy process needs to provide inclusive opportunities and address multiple concerns across political boundaries to address the significant human impact.

The impact of dams is enduring and causes multi-layered ecological harm. The funding of dams fuels the continued harm. The ECA (Export Credit Agencies) Watch, an interest group, harshly criticized the funding and ultimate construction of large dams. The group is particularly concerned with the illusory notion that hydroelectric energy somehow mitigates the harmful effects of dams. The group revealed:

"At least 45,000 large dams have been built on the earth's rivers, and between 40 and 80 million people have been displaced by reservoirs. In the wake of the climate crisis, a new hydro-power boom is currently underway, with thousands of more dams under construction or planned. In main dam building countries like China, Brazil and Turkey virtually no rivers will be unaffected. Dams are not as climate-friendly as the dam industry propagates, as in many cases huge amounts of methane are emitted during the land clearing and construction phase."

The dam industry has considerable resources to shape the ultimate outcomes. Inhabitants of the watershed areas have little recourse. The magnitude of harm is remarkable. The human impact is further underscored by a by a report from Inter Press Service (June 20, 2013):

"The future of food security in the Mekong region lies at a crossroads, as several development ventures, including the Xayaburi Hydropower Project, threaten to alter fish migration routes, disrupt the flow of sediments and nutrients downstream, and endanger millions whose livelihoods depend on the Mekong River basin's resources. Running through China, Myanmar (formerly Burma), Laos, Thailand and Cambodia to the Mekong Delta in Vietnam, this is Asia's seventh longest transboundary river. An estimated 60 million people live within the lush river basin, and nearly 80 percent depend on the Lower Mekong's waters and intricate network of tributaries as a major source of food."

The push for hydroelectric power is allowed without any political resistance despite the lasting social and ecological legacy. The Mekong example illustrates the need to consider the social and ecological terms from a multi-state model. The reality is that the moneyed agents are able to perpetuate dam growth and cause considerable harm. The dam actions and inactions impact millions. Yet, the millions of people are powerless in the policy process.

The size of the dam is not the issue as further noted by the FAO (United Nations Food and Agriculture Organization), small dams can cause the loss of traditional food producing activities such as fishing. "The construction of barriers across rivers has negative impacts on the natural fish populations and contributes to a large degree, together with other factors, to the diminished abundance, disappearance or even extinction of species. This has negative implications for both biodiversity and fisheries."

Policymakers also need to address dam failures. As noted by Pisaniello, dam accidents have caused significant fatalities. For example, Stava Tailings Dam (Italy) failed in 1985 and released only 180 megaliters of tailings material but killed 268 people and caused a serious environmental impact." (Pisaniello, 2011:517-518). Pisaniello's research also illustrates that the deaths occur regardless of dam dimensions: 
"It is true that large dams' failures are more spectacular and receive more "newsworthy" attention than those of smaller dams. However, small dam failures and in particular those that are privately-owned are far more frequent in their occurrence; consequently, small dams' total annual costs can be much higher than the rare (if admittedly more spectacular) failures of large dams."

The vignettes of dam concerns are voluminous. Noted water law expert Professor Tarlock (2012:62) provides a cogent summary:

"The list of cons is long, and the conventional assumption is that the cons outweigh the pros. Hydro's fate is entwined with the opposition to large dams on economic, environmental, and social grounds. Dams have multiple adverse impacts. They change river flows and the fish runs that depend on them, alter river chemistry, change riverine landscapes, and inundate large areas including Indian reservations and scenic canyons and valleys."

To underscore the cost-benefit analysis, Denis Goulet (2005:883) offers the following:

"Large dams were long viewed as the best means of providing abundant and cheap non-polluting electrical power, water for irrigation and domestic and industrial consumption, and flood and drought control.... Even alleged benefits of large dams are now branded as inimical to development, and major conflict attends their construction."

Dam development impacts are well beyond the jurisdiction of a particular state. And, on the micro level, the impact of dam development is felt at the individual level. Traditional ways of life are challenged. It is difficult for individuals to halt dam developments. The policy process is guided by corporate forces. Formal governmental processes neglect to empower the individual and the processes certainly do not go beyond artificial political borders. There are many sectors that support dams. The obvious forces are often those associated with hydroelectric power.

\section{THE POLICY FIGHT: HYDROELECTRIC PUSH FOR DAMS}

Despite the serious and numerous critiques regarding dams, the advocates for dams remain wellpositioned. The search for renewable energy reinforces the political support for dam maintenance and construction. Policymakers are confronted by intensely different policy actors. The recent position by the World Bank illustrates the on-going tensions.

As noted previously, the World Bank in 2000 supported the World Commission on Dams call to temper dam development due to the harm dams had on people and the environment. In 2013 the World Bank retreated from this support. The retreat was driven by the hydroelectric forces. As reported by Schneider in the Washington Post (May 9, 2013):

"The World Bank is making a major push to develop large-scale hydropower projects around the globe, something it had all but abandoned a decade ago but now sees as crucial to resolving the tension between economic development and the drive to tame carbon use... Major hydropower projects in Congo, Zambia, Nepal and elsewhere - all of a scale dubbed "transformational" to the regions involved - are a focus of the bank's fundraising drive among wealthy nations. Bank lending for hydropower has scaled up steadily in recent years, and officials expect the trend to continue amid a worldwide boom in water-fueled electricity."

The push for energy seemingly muffles the concerns that dams threaten life, food security, and, ecology. Financing dams will perpetuate dams. The report offers a glimpse into the dam policy future:

"The major nations that support the World Bank, however, have been pushing it to identify such projects - complex undertakings that might happen only if an international organization is involved in sorting out the financing, overseeing the performance and navigating the politics."

The change to a global governance solution is decreased by the intensely committed positions represented by the World Bank constituents and the opponents of hydropower. Environmental groups are not unaccustomed to fighting prolonged political battles. 
Some non-governmental organizations (NGOs) expressed concerned over what was perceived as a World Bank position reversal. A serious response was offered by the Berne Declaration, a Swiss non-governmental organization with a membership of 20,000. The May 1, 2013 response to the World Bank position read:

"The Berne Declaration and the South Asia Network on Dams, Rivers and People protest against the World Bank's refusal to accept the recommendations of the World Commission on Dams report. In a letter to President Wolfensohn which was endorsed by 85 other groups from 30 countries, they say that if the Bank does not comprehensively adopt the WCD's recommendations, NGOs will hesitate to engage in other dialogues with the Bank in the future."

The challenge then to world decision-makers is to address the competing forces. Global governance is needed to sort through the harsh realities of the dam proponents as well as the possible benefits. As policy fights on a global scale persist between hydro and dam opponents, other concerns exist. Water, whether from dams or other sources, is essential to food production.

\section{GLOBAL POLICY STRATEGY}

Mother Nature has no boundaries and from an environmental perspective this demands that attention be paid to a global perspective. Dam policy ought not to escape community and global scrutiny. Just as the herdsmen in Garret Hardin's, The Tragedy of the Commons needed to heed the action of others, so is the case for all associated with dams. Elinor Ostrom (1990) underscores the need for cooperation. We cannot continually develop and rely on dams without recognizing the many negative as well as positive possibilities. Dam policy must reconcile layers of demands ranging from the human impact, stewardship, and hydroelectric demands and build policies based on broader policies of global governance and comparative policy.

The value of comparing regimes drove Aristotle to examine 158 different constitutions (von Fritz \& Kapp, 1950). Heidenheimer, et cetera offer that comparative public policy... "illuminates the various ways in which politics works to produce choices of a collective and social nature" (983:2). Good policies and laws can be ascertained through a comparative and global approach far too absent in the dam milieu.

The policy process must further provide an equilibrium in which the highly resourced interests are placed on equal footing with the poorly resourced. The policy process demands attention to the complexity of nations, political actors, science, and many more variables. An illustration of how the policy might unfold involves Warren Buffett and the Klamath Tribes. Warren Buffett has extensive holdings in PacifCorp, a provider of power in the Pacific states. PacifiCorp utilizes a number of dams for hydroelectric power. The Klamath Tribes for years have pressured Warren Buffett to remove the dams and thus restore tribal fishing practices, practices utilized long-before white settlements.

After a protracted fight, the Klamath Tribes seemingly have prevailed. The Klamath Hydroelectric Relicensing Agreement (KHRA) targets 2020 as the removal date of PacifiCorp's dams.

The main points of this agreement are stated as:

"KHRA, lays out the process for conducting necessary additional studies, environmental reviews, and a decision by the Secretary of the Interior as to whether 1) removal of the lower four dams on the Klamath River owned by PacifiCorp will advance restoration of the salmonid fisheries of the Klamath Basin, and 2) removal of dams is in the interest of Tribes, local communities, and the general public. The Hydroelectric Settlement includes provisions for the interim operation of the dams prior to dam removal as well as the process to transfer, decommission, and remove the dams."

The policy lesson from the KHRA underscores the importance of "Ostrom-like" cooperation possibilities. As Jeff Mitchell, council member for the Klamath Tribes of Oregon stated: "Once we decided to stop fighting and start talking, we realized the opportunities provided by collaboration and coalition building." (Tenders Info October 3, 2009 Saturday United States: Historic Klamath Dam Removal Agreement Released Today). But, any cooperative 
model needs to include the hydroelectric forces as well. The cast of characters ought to be lengthy and diverse. The lack of diverse participants only inflames and perpetuates conflict.

Such is the case of the Klamath. Despite the initial feelings of cooperative success, the policy process is still unfolding. There seems to be concern that PacifiCorp remains interested in pushing against dam removal and the resulting Klamath Basin restoration (Klamath Basin Restoration Agreement or KBRA). As argued by Hayley Hutt, a member of the Hoopa Valley Tribal Council:

"It is time to return to public processes and take the dams out. PacifiCorp stated that relicensing the dams is uneconomical. Anyone who believes that Warren Buffett cannot surrender the dams without the KBRA is ignoring the facts. No amount of stalling will keep these dams from falling."

The Klamath River example illustrates the conflicting influences on dam policy. Policy makers are indeed confronted by intensely different forces. Depending on the tipping of influences, dams may or may not persist on the Klamath River. More importantly, the Klamath example illustrates the importance of building a legitimate policy process. The process allowed multiple access points for stakeholders. The policy process must address the detrimental impacts resulting from the very existence of a dam. The political process ought to consider lessons from accounting so as to calibrate a balanced solution.

\section{ENVIRONMENTAL ACCOUNTING}

Inventories of dams are beneficial. The United Nations FAO (Food and Agricultural Organization) provides key information through AQUASTAT.

AQUASTAT gathers detailed information about dams in each country during country update processes. AQUASTAT's data was important, especially for African dams.

The dam accounting can be part of an environmental accounting. An environmental accounting system is far from simple. An environmental accounting system not only considers the economic input, processes and output for accounting of a limited resource like water but is umbilically juxtaposed to the many political and environmental needs of its stakeholders that continually provide feedback for updating and improving the system. Yet, a comprehensive system can result in better efficiencies at the market and environmental levels.

To simplify, an environmental accounting system for water should include approaches in how one acquires water and a process of prioritization as to how the water will be distributed. The flashpoint usually seems to surround the issue of "who decides" and "who will benefit." Environmental accounting systems for water of old have focused on allocating water based on a benefit-cost analysis or developing a process of dividing the pie based on determined priorities. Yet the environmental water account may provide a proactive approach of budgeting current and future water needs. As Sinclair, Knight, Mertz (2006) describe the water accounts which contain opening water balances, inflows, outflows, and ending balances for the specific period.

Plummer and Tower (2010) discuss how the United Nations Statistics Division (UNSD) created the System of Environmental and Economic Accounting for Water (SEEAW) which emphasizes the type of information that can be made available in five key categories: 1) physical supply and use tables; 2) hybrid and economic accounts; 3 ) assets accounts; 4) quality accounts; 5) valuation accounts. Perhaps environmental accounting for water can assist in balancing the needs for water into the future.

\section{FUTURE: WATER AND FOOD}

The challenge is to secure water for survival. Dams, groundwater, surface water... all require careful balance. Lester Brown warns ...restoring the earth's natural systems and resources incorporates a worldwide initiative to arrest the fall in water tables by raising water productivity: the useful activity that can be wrung from each drop. That implies shifting to more efficient irrigation systems and to more water-efficient crops. In some countries, it implies growing (and eating) more wheat and less rice, a water-intensive crop. And for industries and cities, it implies doing what some are doing already, namely, continuously recycling water (p. 56). 
Water policy then must include a comprehensive global approach. As seen in the many negative dam vignettes, dams can be fatal to humans. Dams often destroy traditional agricultural practices and displace hundreds of millions of world citizens. Dams frequently are for energy and not always for food thereby removing a possible key factor in dam construction and maintenance. The policy process must be constructed so as to assure that water is used in a fashion to mitigate hunger and better promote world populations.

\section{CONCLUSION}

Dams no doubt cause harmful impacts to humans and to the larger ecological systems. Governments must address the global implications of dams. Policies must be formulated from inclusive participation and these policies must balance competing interests. Water for food should serve as common ground as global policies are constructed.

\section{AUTHOR INFORMATION}

Peter Longo, Ph.D., Professor of Political Science, University of Nebraska-Kearney, USA. E-mail: longop@unk.edu

Richard Cummings, Ph.D., Professor of Accounting, University of Wisconsin-Whitewater, USA. E-mail: cummingr@uww.edu (Corresponding author)

\section{REFERENCES}

1. Aristotle's Constitution of Athens and Related Texts. Translated with an Introduction and Notes by Kurt von Fritz and Ernst Kapp. New York: Hafner Publishing Company. 1950.

2. Berne Declaration. (2013). http://www.evb.ch/en/p474.html

3. Brown, Lester R. (2009). Could Food Shortages Bring Down Civilization? Scientific American (May 2009), 300, 50-57.

4. ECA Watch. Large Dams. http://www.eca-watch.org/issues/large-dams

5. Food and Agriculture Organization of the United Nations (2013) AQUASTATS. http://www.fao.org/nr/water/aquastat/dams/index.stm

6. Food and Agriculture Organization of the United Nations (2013) Dams, Fish, and Fisheries. http://www.fao.org/fishery/topic/14785/en

7. Goulet, D. (2005). Global Governance, Dam Conflicts, and Participation, Human Rights Quarterly, 27(2005) 881-907.

8. Hardin, G. (1968). Tragedy of the Commons, Science, 162, 1243-1248.

9. Heidenheimer, A.J., Heclo, H., and Adams C.T., (1983). Comparative Public Policy, The Politics of Social Choice in Europe and America (2 ed.). St. Martin's Press New York.

10. Hutt, H. (2012) Facts and fiction on the Klamath River Settlement Process and dam removal. Eureka Times Standard. August 2, 2012.

11. Klamath Hydroelectric Relicensing Agreement. (2010). http://www.pacificorp.com/es/hydro/hl/kr.html\#

12. Ostrom, E. (1990). Governing the Commons. Cambridge Press, Cambridge, U.K.

13. Pisaniello, J. (2011). A Comparative Review of Environmental Protection Policies and Laws Involving Hazardous Private Dams: 'Appropriate' Practice Models for Safe Catchments. William \& Mary Environmental Law and Policy Review, 35, 515.

14. Plummer, J. and Tower, G. (2010). No Accounting for Water: Conflicting Business and Science Viewpoints. International Business and Economics Research Journal, 9(September 2010), 65-76.

15. Richter, B.D.; Postel, S.; Revenga, C.; Scudder, T.; Lehner, B.; Churchill, A. and Chow, M. (2010). Lost in development's shadow: The downstream human consequences of dams. Water Alternatives, 3(2): 14-42. http://www.water-alternatives.org/index.php?option=com_content\&task=view\&id=99\&Itemid=1

16. Russeau, S.S.K. (2013). Dams Threaten Mekong Basin Food Supply. Inter Press Service (June 20, 2013). http://www.ipsnews.net/2013/06/dams-threaten-mekong-basin-food-supply/

17. Schneider, H. (2013). World Bank changes course on dam-building. Washington Post (May 9, 2013). 
18. Sinclair, Knight, Mertz (2006). Stocktake and Analysis of Australia's Water Accounting Practice. Final Report. Sinclair Knight Mertz: Tatura Victoria, Australia.

19. Tarlock, D. (2012). Hydro Law and the Future of Hydroelectric Power Generation in the United States. Vanderbilt Law Review, 65m, 1723-1767

20. Tenders Info (2009). Historic Klamath Dam Removal Agreement Released Today

21. World Commission on Dams (2000). http://www.internationalrivers.org/files/attachedfiles/world_commission_on_dams_final_report.pdf 


\section{NOTES}

